\title{
Postpartum tubo-ovarian abscess, likely arising from pelvic inflammatory disease during pregnancy
}

\author{
Rania Abdou, Trent Miller
}

Obstetrics and Gynaecology, St George Hospital, Kogarah, Australia

\section{Correspondence to} Dr Rania Abdou, abdou.rania@gmail.com

Accepted 3 April 2017

\section{(1) CrossMark}

To cite: Abdou R, Miller T. BMJ Case Rep Published Online First: [please include Day Month Year]. doi:10.1136/bcr-2017220183

\section{DESCRIPTION}

A female aged 18 years presented 2 weeks postnormal vaginal delivery with worsening generalised abdominal pain radiating to the back since delivery, with associated night sweats. She was vomiting, had loose bowel motions and had difficulty passing urine, but denied dysuria. On examination, she was febrile, tachypnoeic and tachycardic, and had a pale complexion. Her abdomen was distended with maximal tenderness in the left illiac fossa and associated rebound and percussion tenderness. She was unable to pass urine in the emergency department. Blood tests demonstrated a raised white cell count, $\mathrm{C}$ reactive protein 344 and CA-125 145.

She had a CT abdomen which showed a large pelvic abscess (figure 1 and figure 2) with internal septations posterior to the uterus (figure 3) and bilateral hydronephrosis and hydroureter. She was given intravenous antibiotics and underwent a laparotomy with drainage of pelvic abscess. Intraoperative findings included an extensive pelvic abscess containing purulent fluid, contained by a thick-walled peritoneum and omentum which were oedematous. The abscess appeared to be arising from a right tubo-ovarian abscess, with purulent exudate throughout the pelvis and gross appearance of acute salpingitis. The small and large bowel were also noted to be oedematous. In total, $2.9 \mathrm{~L}$ of pus was drained and the abdomen was extensively washed out. Histopathology of the omental biopsy showed inflamed and haemorrhagic granulation tissue consistent with abscess wall. Cyst fluid cytology showed degenerate acute inflammatory cells, consistent with an abscess.

On examination of her obstetric ultrasounds, it became clear that she had increasing amounts of free fluid in the pelvis with $98 \mathrm{~mL}$ in the Pouch of

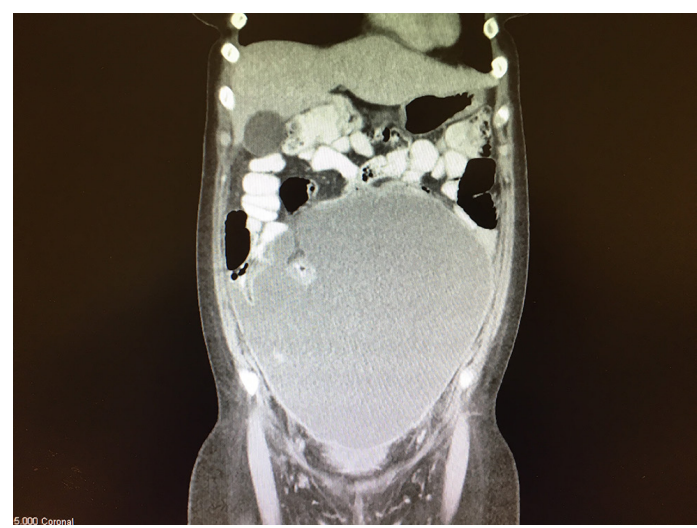

Figure 1 A horizontal view of the large complex pelvic cystic lesion.

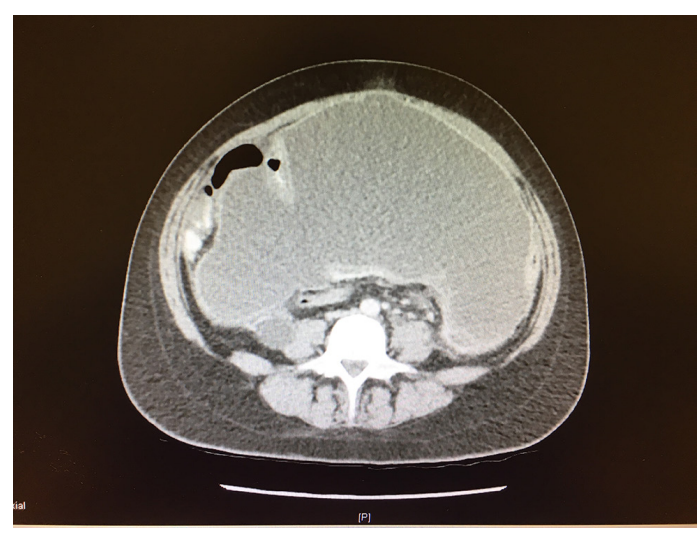

Figure 2 A transverse view of the large complex pelvic cystic lesion.

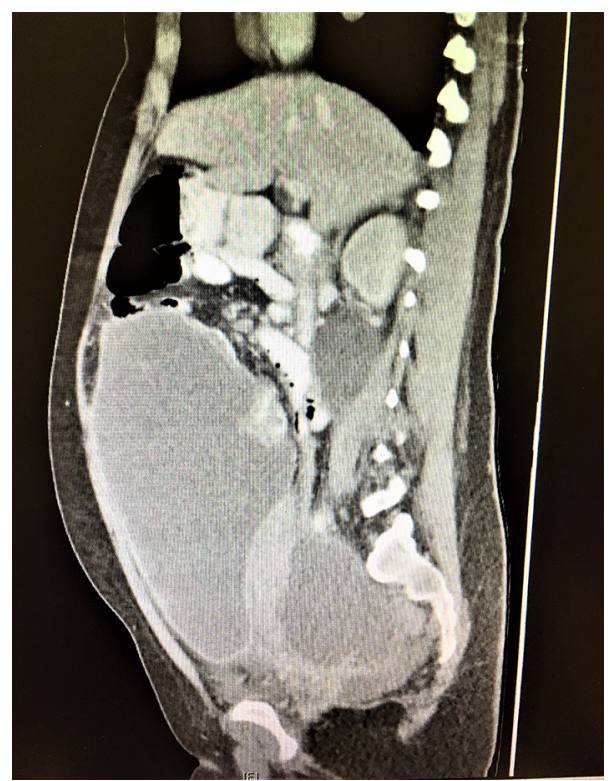

Figure 3 A large cystic lesion within the pelvis anterior to the uterus with internal septations measuring $13 \times 22 \mathrm{~cm}$ in axial and $24 \mathrm{~cm}$ craniocaudally. A second complex cystic lesion with internal septation posterior to the uterus measuring $10 \times 10 \mathrm{~cm}$ in axial and $12 \mathrm{~cm}$ craniocaudally.

Douglas at the 19-week ultrasound. The impression was of rare pelvic inflammatory disease in pregnancy, which developed into right tubo-ovarian abscess with acute salpingitis post partum. She recovered well postoperatively and was discharged home on oral antibiotics with uneventful follow-up. 


\section{Learning points}

- Pelvic inflammatory disease (PID) in pregnancy is rare, ${ }^{12}$ and the triad of fever, leukocytosis and diarrhoea can indicate formation of tubo-ovarian abscess in a patient with PID. ${ }^{2}$

- Increased C reactive protein and CA-125 levels are independent factors predictive of tubo-ovarian abscess in acute PID. ${ }^{3}$

- Large tubo-ovarian abscesses can cause sepsis and hydronephrosis with urinary retention.

Contributors RA formulated the concept of this article. RA and TM cared for this patient during her admission and follow-up. RA researched this topic and wrote this case report, and TM edited this article.
Competing interests None declared.

\section{Patient consent Obtained.}

Provenance and peer review Not commissioned; externally peer reviewed.

(c) BMJ Publishing Group Ltd (unless otherwise stated in the text of the article) 2017. All rights reserved. No commercial use is permitted unless otherwise expressly granted.

\section{REFERENCES}

1 Navada HM, Bhat BP. Pelvic inflammatory disease in the form of peritoneal abscess complicating late pregnancy. Case Rep Obstet Gynecol 2011;2011:851598.

2 Sordia-Hernández LH, Serrano Castro LG, Sordia-Piñeyro MO, et al. Comparative study of the clinical features of patients with a tubo-ovarian abscess and patients with severe pelvic inflammatory disease. Int I Gynaecol Obstet 2016;132:17-19.

3 Lee SW, Rhim CC, Kim JH, et al. Predictive markers of Tubo-Ovarian abscess in pelvic inflammatory disease. Gynecol Obstet Invest 2016;81:97-104.

Copyright 2017 BMJ Publishing Group. All rights reserved. For permission to reuse any of this content visit http://group.bmj.com/group/rights-licensing/permissions.

BMJ Case Report Fellows may re-use this article for personal use and teaching without any further permission.

Become a Fellow of BMJ Case Reports today and you can:

- Submit as many cases as you like

- Enjoy fast sympathetic peer review and rapid publication of accepted articles

- Access all the published articles

Re-use any of the published material for personal use and teaching without further permission

For information on Institutional Fellowships contact consortiasales@bmjgroup.com

Visit casereports.bmj.com for more articles like this and to become a Fellow 